\title{
Cement-Wood Composites: Effects of Wood Species, Particle Treatments and Mix Proportion
}

\author{
M. R. Garcez ${ }^{1, *}$, E. O. Garcez ${ }^{2}$, A. O. $\operatorname{Machado}^{2}$, D. A. Gatto ${ }^{2}$ \\ ${ }^{1}$ Interdisciplinary Department, Federal University of Rio Grande do Sul (UFRGS), Brazil \\ ${ }^{2}$ Engineering Center, Federal University of Pelotas (UFPel), Brazil
}

\begin{abstract}
The aim of this research was to investigate the effects of wood species, particle treatments and mix proportion on the physical (density) and mechanical (compressive strength and dynamicmodulus of elasticity) properties of cement-wood composites. Different mix proportions were investigated, based on the cement: wood ratio of 0.3:0.7, in volume, with Pinus elliottii and Eucalyptus grandis sawdust percentages of 0-100, 25-75, 50-50, 75-25 or 100-0. Sawdust particles were pre-treated with either lime or cement coating to improve cement and wood compatibility. Results show that wood species, particle treatments and mix proportions may influence the physical and mechanical properties of cement-wood composites. In general, results confirm that Eucalyptus sawdust and cement are naturally compatible and do not require any previous particle treatment to avoid compatibility problems.
\end{abstract}

Keywords Pinus elliottii, Eucalyptus grandis, Lime, Cement, Sawdust, Waste

\section{Introduction}

Brazil is one of the five largest producers of industrial round wood with USA, Russian Federation, China and Canada. These countries produced in $201354 \%$ of total global production [1]. As consequence, huge quantities of wood waste are produced annually by sawmills, whose improper disposal can lead to environmental damage and economic concerns for wood companies.

Plant biomass has already being used to produce engineering materials, encompassing technological and scientific aspects as well as economic, environmental and social issues [2]. The use of wood in cement matrix, in particular, has been investigated for more than one hundred years, whereas its industrial utilization has started later. Initially, small wood particles were embedded in cement matrixto produce low-density boards mainly used for insulating purposes [3]. However, recent studies have also investigated the use of wood waste as raw material for manufacture of many other composites such as wood-based panels, cement slabs and plastic-wood [4].

Wood waste in form of fibers, particles or strands have the potential to be used as reinforcing agent or filler in cement composites [3, 5-9].Cement-wood composites have many advantages over other conventional wood materials, including better insulation and fire performance, better resistance to water soaking, better bactericidal properties

* Corresponding author:

mrgarcez@hotmail.com (M. R. Garcez)

Published online at http://journal.sapub.org/cmaterials

Copyright (C) 2016 Scientific \& Academic Publishing. All Rights Reserved and higher stiffness [5].

Wood fibers, as natural fibers, are composed by three major components: cellulose, hemicellulose and lignin. The relative portion of these components may vary based on the types of fibers and the plant source [2]. For some specific applications, certain chemical elements may have to be removed [10].

Due to the chemical morphology of cement and cellulose, hydrogen bonding and/or hydroxyl bridges may play a major role in the bonding of these components [3]. On the other hand, hemicelluloses, starches, sugars, phenols and acids existing in wood fibers, at different levels for each wood specie, tend to inhibit cement hydration, not only leading to a longer setting time but also limiting the strength of the cementitious composite due to micro-fracturing of the matrix during cement hydration $[3,6]$.The complex system of cement hydration reactions itself is influenced by the concentration of $\mathrm{Ca}(\mathrm{OH})_{2}, \mathrm{pH}$ and temperature. Different conditions determine different yields for the reactions and different stabilities for the final products [11]. Inhibition of cement hydration occurs when the calcium silicate hydrate (C-S-H) nucleation sites, which are originally positively charged surfaces, are poisoned by the sugar-acid anions. The wood-fiber surface is probably the most likely place to find the inhibitory effects, related cement hydration [7].

Variability in properties of natural fibers, in general, depends on the growing environment (temperature, humidity, soil composition, air and age) but also depends on the way the plants are harvested and processed [2]. Therefore, physical and mechanical properties of cement-wood composites are strongly influenced by the wood species used in the manufacture, as well as by wood 
content [3], wood particle size $[3,4]$ and particle treatments $[3,5,7,8]$.

The main purpose of this study was to investigate the effects of two wood species, three particle treatments and fifteen different mix proportions, on the physical and mechanical behavior of cement-wood composites, through the analysis of density, compressive strength and dynamic modulus of elasticity.

\section{Materials and Methods}

\subsection{Materials}

Brazilian cement CPV-ARI [12] similar to Portland cement Type III - HESC - High Early Strength Cement (ASTM C150-12) was used as binder.

Pinus elliottii and Eucalyptus grandis wastes were obtained from a wood processing industry, located in Southern Brazil. Two particle treatments were used:

Cement coating [13], which consisted in mixing wet sawdust and cement, with a sawdust: cement ratio of 8:1 in volume;

Immersion of sawdust particles in a saturated lime solution [5]prepared with Calcium Hydroxide type CH II [14] with a sawdust: water: $\mathrm{Ca}(\mathrm{OH})_{2}$ ratio of 1:1:0.05 in mass, for 24 hours, followed by a brief washin running tap water.

Figure 1 shows in natura and pre-treated sawdust particles, namedaccording to the wood specie and particle treatment: $P_{\text {nat }}\left(\rho_{\text {un }} 0,21 \mathrm{~g} / \mathrm{cm}^{3}\right), P_{\text {cem }}\left(\rho_{\text {un }} 0,29 \mathrm{~g} / \mathrm{cm}^{3}\right), P_{\text {alk }}\left(\rho_{\text {un }} 0,21 \mathrm{~g} / \mathrm{cm}^{3}\right)$, $\mathrm{E}_{\text {nat }}\left(\rho_{\text {un }} 0,22 \mathrm{~g} / \mathrm{cm}^{3}\right), \quad \mathrm{E}_{\text {cem }}\left(\rho_{\text {un }} 0,30 \mathrm{~g} / \mathrm{cm}^{3}\right) \quad$ and $\mathrm{E}_{\mathrm{alk}}\left(\rho_{\mathrm{un}} 0,23 \mathrm{~g} / \mathrm{cm}^{3}\right)$, for Pinus elliottii and Eucalyptus grandis species with natural, cement and alkaline treatments, respectively.
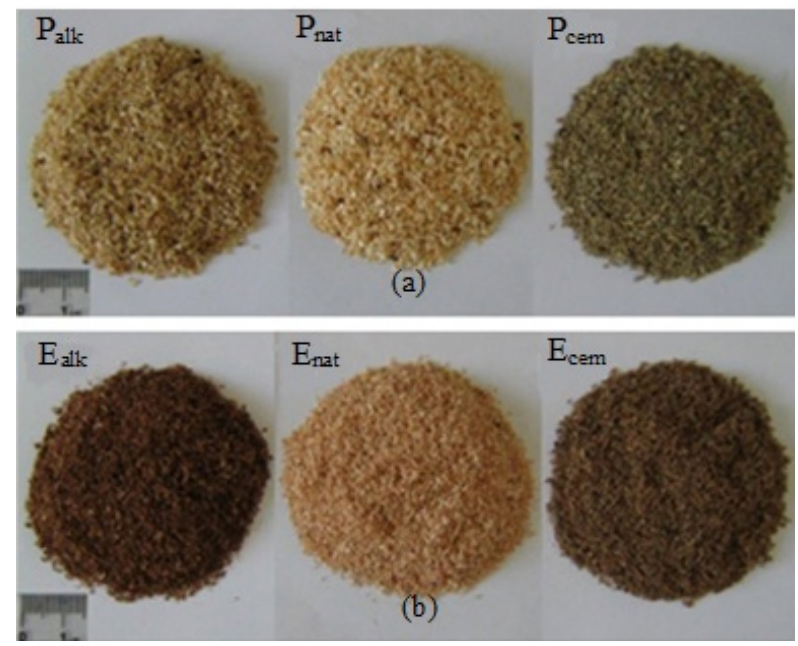

Figure 1. In natura and pre-treated sawdust particles: (a) Pinus elliottii; (b) Eucalyptus grandis
Table 1 shows chemical composition of pre-treated sawdust samples, obtained by X-Ray fluorescence (XRF).

Table 1. Chemical composition of Sawdust

\begin{tabular}{ccccccc}
\hline \multirow{2}{*}{$\begin{array}{c}\text { Chemical } \\
\text { Elements }\end{array}$} & $\mathrm{P}_{\text {nat }}$ & $\mathrm{P}_{\text {cem }}$ & $\mathrm{P}_{\text {alk }}$ & $\mathrm{E}_{\text {nat }}$ & $\mathrm{E}_{\text {cem }}$ & $\mathrm{E}_{\text {alk }}$ \\
\hline $\mathrm{Ca}$ & 51.11 & 85.42 & 90.91 & 43.25 & 83.51 & 94.14 \\
$\mathrm{Mn}$ & 24.03 & 0.44 & 5.71 & 16.92 & 0.24 & 3.03 \\
$\mathrm{Fe}$ & 7.70 & 7.10 & 3.38 & 13.88 & 7.45 & 2.34 \\
$\mathrm{~K}$ & 9.58 & 0.60 & - & - & 1.60 & - \\
$\mathrm{Cu}$ & 7.59 & - & - & 10.43 & - & - \\
$\mathrm{Er}$ & - & - & - & 15.52 & - & - \\
$\mathrm{Si}$ & - & 4.23 & - & - & 4.40 & - \\
$\mathrm{S}$ & - & 1.21 & - & - & 1.58 & - \\
$\mathrm{Sr}$ & - & 1.04 & - & - & 1.23 & - \\
\hline
\end{tabular}

Figure 2 shows sawdust waste particle size distributions, after sieving to obtain the dense gradation [15].
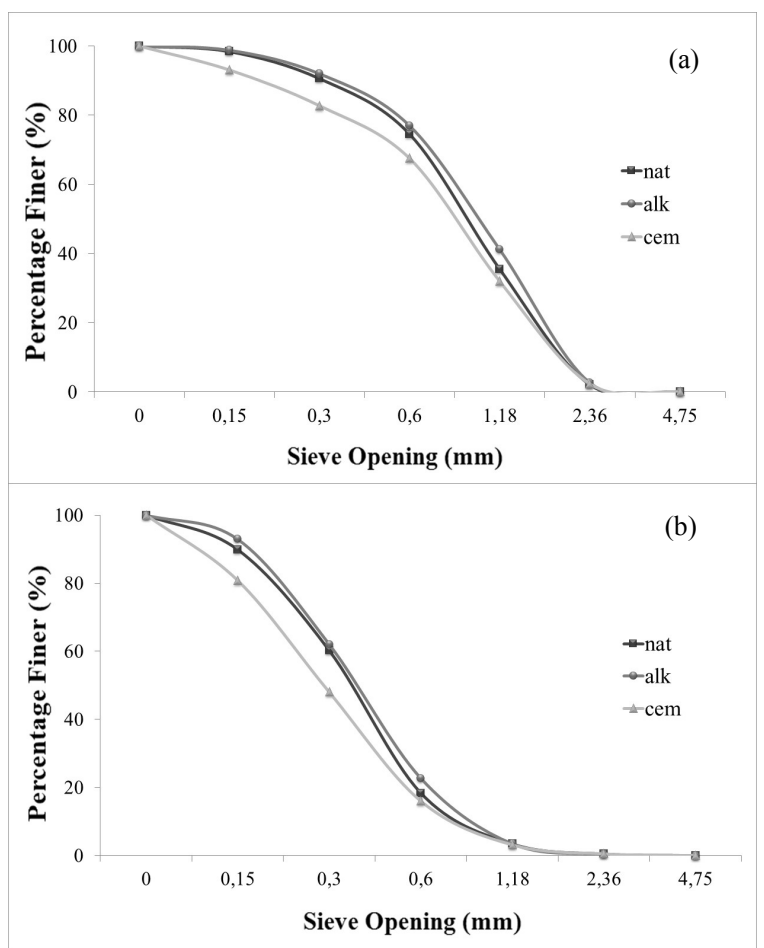

Figure 2. Particle size distribution: (a) Pinus elliottii; (b) Eucalyptus grandis

\subsection{Mix Proportions and Manufacture}

Mix proportions were defined, based on the cement:wood ratio of 0.3:0.7, in volume, with Pinus elliottii and Eucalyptus grandis sawdust percentages of 100-0, 75-25, 50-50, 25-75 and 0-100, as shown in Table 2. 
Table 2. Mix proportion, in volume

\begin{tabular}{|c|c|c|c|c|c|c|c|c|}
\hline \multirow{2}{*}{ Composites } & \multirow{2}{*}{ Cement (\%) } & \multirow{2}{*}{ Wood (\%) } & \multicolumn{6}{|c|}{ Type of sawdust (\%) } \\
\hline & & & $\mathrm{P}_{\text {nat }}$ & $\mathrm{P}_{\mathrm{cem}}$ & $\mathrm{P}_{\text {alk }}$ & $E_{\text {nat }}$ & $\mathrm{E}_{\mathrm{cem}}$ & $\mathrm{E}_{\text {alk }}$ \\
\hline $\mathrm{P} 100 \mathrm{E} 0_{\text {nat }}$ & & & 100 & - & - & - & - & - \\
\hline $\mathrm{P} 100 \mathrm{E} 0_{\mathrm{cem}}$ & & & - & 100 & - & - & - & - \\
\hline $\mathrm{P} 100 \mathrm{E} 0_{\text {alk }}$ & & & - & - & 100 & - & - & - \\
\hline P75E25 nat & & & 75 & - & - & 25 & - & - \\
\hline $\mathrm{P} 75 \mathrm{E} 25_{\mathrm{cem}}$ & & & - & 75 & - & - & 25 & - \\
\hline P75E25 alk & & & - & - & 75 & - & - & 25 \\
\hline $\mathrm{P} 50 \mathrm{E} 50_{\text {nat }}$ & & & 50 & - & - & 50 & - & - \\
\hline $\mathrm{P} 50 \mathrm{E} 50_{\mathrm{cem}}$ & 30 & 70 & - & 50 & - & - & 50 & - \\
\hline $\mathrm{P} 50 \mathrm{E} 50_{\mathrm{akl}}$ & & & - & - & 50 & - & - & 50 \\
\hline $\mathrm{P} 25 \mathrm{E} 75_{\text {nat }}$ & & & 25 & - & - & 75 & - & - \\
\hline $\mathrm{P} 25 \mathrm{E} 75_{\mathrm{cem}}$ & & & - & 25 & - & - & 75 & - \\
\hline P25E75 alk & & & - & - & 25 & - & - & 75 \\
\hline P0E100 ${ }_{\text {nat }}$ & & & - & - & - & 100 & - & - \\
\hline $\mathrm{P} 0 \mathrm{E} 100_{\mathrm{cem}}$ & & & - & - & - & - & 100 & - \\
\hline P0E100 alk & & & - & - & - & - & - & 100 \\
\hline
\end{tabular}

Manufacture process consisted in mixing cement, water and sawdust contents (Table 3) in a planetary mortar mixer, placing five samples of each composite in cylindrical $\$ 20 \mathrm{mmx} 40 \mathrm{mmmetallic}$ molds. After seven curing days, samples were demolded and conditioned in a laboratory room, protected from air currents and direct insulation, for 21 days.

Table 3. Mix proportion, in mass

\begin{tabular}{|c|c|c|c|c|c|c|c|c|}
\hline \multirow{2}{*}{ Composites } & \multirow{2}{*}{ Cement } & \multirow[t]{2}{*}{ Water } & \multicolumn{6}{|c|}{ Sawdust } \\
\hline & & & $\mathrm{P}_{\text {nat }}$ & $\mathrm{P}_{\mathrm{cem}}$ & $\mathrm{P}_{\text {alk }}$ & $\mathrm{E}_{\text {nat }}$ & $\mathrm{E}_{\mathrm{cem}}$ & $\mathrm{E}_{\text {alk }}$ \\
\hline $\mathrm{P} 100 \mathrm{E} 0_{\text {nat }}$ & & & 0.483 & - & - & - & - & - \\
\hline $\mathrm{P} 100 \mathrm{E} 0_{\mathrm{cem}}$ & & & - & 0.667 & - & - & - & - \\
\hline $\mathrm{P} 100 \mathrm{E} 0_{\text {alk }}$ & & & - & - & 0.483 & - & - & - \\
\hline P75E25 nat & & & 0.362 & - & - & 0.127 & - & - \\
\hline $\mathrm{P} 75 \mathrm{E} 25_{\mathrm{cem}}$ & & & - & 0.500 & - & - & 0.173 & - \\
\hline $\mathrm{P} 75 \mathrm{E} 25_{\mathrm{alk}}$ & & & - & - & 0.362 & - & - & 0.132 \\
\hline P50E50 nat & & & 0.242 & - & - & 0.253 & - & - \\
\hline $\mathrm{P} 50 \mathrm{E} 50_{\mathrm{cem}}$ & 1 & 0.6 & - & 0.334 & - & - & 0.345 & - \\
\hline $\mathrm{P} 50 \mathrm{E} 50_{\mathrm{akl}}$ & & & - & - & 0.242 & - & - & 0.265 \\
\hline $\mathrm{P} 25 \mathrm{E} 75_{\text {nat }}$ & & & 0.121 & - & - & 0.380 & - & - \\
\hline $\mathrm{P} 25 \mathrm{E} 75_{\mathrm{cem}}$ & & & - & 0.167 & - & - & 0.518 & - \\
\hline $\mathrm{P} 25 \mathrm{E} 75_{\text {alk }}$ & & & - & - & 0.121 & - & - & 0.397 \\
\hline P0E100 ${ }_{\text {nat }}$ & & & - & - & - & 0.506 & - & - \\
\hline $\mathrm{P} 0 \mathrm{E} 100_{\mathrm{cem}}$ & & & - & - & - & - & 0.690 & - \\
\hline P0E100 alk & & & - & - & - & - & - & 0.529 \\
\hline
\end{tabular}

\subsection{Physical and Mechanical Properties}

Cement-wood composites performance, regarding wood species, particle treatments and mix proportions, were evaluated through physical and mechanical properties.

Density

Density was determined by measuring the mass and volume of each sample, according toEquation1, where $\mathrm{M}_{0}$ is the weight $(\mathrm{g}), \mathrm{V}_{0}$ is the volume $\left(\mathrm{cm}^{3}\right)$ and $\rho$ is the density $\left(\mathrm{g} / \mathrm{cm}^{3}\right)$. Results were reported as the average of five measurements.

$$
\rho=\frac{M_{0}}{V_{0}}
$$

Compressive strength and Dynamic Modulus of Elasticity Compressive strength tests were carried in a universal 
testing machine, following a procedure adapted from the Brazilian Technical Standard for Compressive Strength of Cement[16], considering a loading speed of $0,05 \mathrm{MPa} / \mathrm{s}$ and reported as the average of five samples.

Dynamic modulus of elasticity was determined [17] through the measurement of ultrasonic pulse velocity using aTICO Proceq testing device with transducers of $54 \mathrm{~Hz}$. Results were reported as the average of five samples, based on Equation 2, where $\mathrm{V}$ is the ultrasonic pulse velocity $(\mathrm{mm} / \mu \mathrm{s}), \rho$ is the density $\left(\mathrm{kg} / \mathrm{m}^{3}\right)$ and $\mu$ is the Poisson ratio.

$$
E d=V^{2} \rho \frac{(1+\mu)(1-2 \mu)}{(1-\mu)}
$$

\subsection{Statistical Analysis}

Analysis of variance (ANOVA) was performed using the Statgraphics commercial software. Fisher's Least Significant Difference (LSD) test was used to compare the difference among the mean values for the properties at the level of 0.05 .

\section{Results and Discussion}

Trends in the average properties of cement-wood composites values are difficult to ascertain, mainly because wood fibers are a biological material and had inherent variability in fiber length and properties [7]. Apart from that, treatments of each wood fiber may not be uniform over the fiber surface. However, wood specimens, treatments and mix proportions, proposed in this experimental program, resulted in a data set that allowed an examination of apparent trends in the average physical and mechanical properties of cement-wood composites, as discussed in this section.

\subsection{Density}

Figure 3 shows results of density for cement-wood composites, whose values are presented in Table 3 . Results agree with others reported by literature $[3,4,8,11,19]$.

The importance of studying physical properties of cement-wood composites, in particular density, refers to the fact that, in general, the wood incorporation leads to a composite with lower density and, consequently, lower compressive strength $[11,18]$. Cement-wood composites with higher densities also present higher values of modulus of elasticity and modulus of rupture [19]. On the other hand, reduction of density results on lighter elements that could be an advantage regarding handling and transporting.

In this study, density of cement-wood composites was significantly influenced by particle treatments. Composites with sawdust treated by cement coating showed higher density, followed by the ones with in natura sawdust and the ones in which sawdust was immersed in alkaline solution.

Regarding P100E0 that contains only Pinus elliottii sawdust, test results indicate that values of density are higher for cement coating, decreasing when immersion in alkaline solution or in natura sawdust are applied.

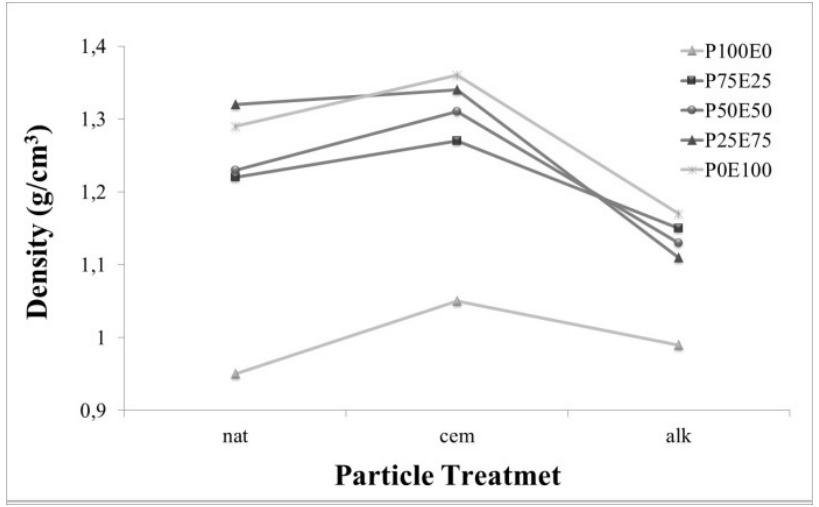

Figure 3. Density of cement-wood composites

Table 3. Density of cement-wood composites

\begin{tabular}{|c|c|c|c|}
\hline \multirow{2}{*}{$\begin{array}{l}\text { Composite } \\
\mathrm{P} 100 \mathrm{E} 0_{\text {nat }}\end{array}$} & \multicolumn{2}{|c|}{$\begin{array}{l}\text { Density } \\
\left(\mathrm{g} / \mathrm{cm}^{3}\right)\end{array}$} & \multirow{2}{*}{$\frac{\mathrm{CV}(\%)}{3.53}$} \\
\hline & 0.95 & a & \\
\hline $\mathrm{P} 100 \mathrm{E} 0_{\mathrm{cem}}$ & 1.05 & c & 3.88 \\
\hline $\mathrm{P} 100 \mathrm{E}_{\mathrm{alk}}$ & 0.99 & b & 0.97 \\
\hline P75E25 $5_{\text {nat }}$ & 1.22 & $\mathrm{f}$ & 2.06 \\
\hline $\mathrm{P} 75 \mathrm{E} 25_{\mathrm{cem}}$ & 1.27 & $\mathrm{~g}$ & 2.36 \\
\hline P75E25 alk & 1.15 & de & 0.83 \\
\hline P50E50 nat & 1.23 & $\mathrm{f}$ & 3.38 \\
\hline $\mathrm{P} 50 \mathrm{E} 50_{\mathrm{cem}}$ & 1.31 & hi & 1.83 \\
\hline $\mathrm{P} 50 \mathrm{E} 50_{\mathrm{akl}}$ & 1.13 & de & 2.54 \\
\hline $\mathrm{P} 25 \mathrm{E} 75_{\text {nat }}$ & 1.32 & hi & 0.72 \\
\hline $\mathrm{P} 25 \mathrm{E} 75_{\mathrm{cem}}$ & 1.34 & ij & 1.49 \\
\hline P25E75 alk & 1.11 & d & 4.09 \\
\hline P0E100 ${ }_{\text {nat }}$ & 1.29 & gh & 1.10 \\
\hline $\mathrm{P} 0 \mathrm{E} 100_{\mathrm{cem}}$ & 1.36 & j & 1.59 \\
\hline P0E100 alk & 1,17 & e & 1.41 \\
\hline
\end{tabular}

$\mathrm{CV}=$ Coefficient of variation. Same letters imply treatments with equivalent means.

On the other hand, composites with Eucaliptus grandis, P0E100, P25E75 P50E50 e P75E25, show a different behavior: density is higher for cement coating, decreasing when in natura sawdust and immersion in alkaline solution particle treatments are applied.

Mix proportions in which blends of both wood species were used (P25E75 P50E50 e P75E25) and sawdust particles were immersed in alkaline solution showed the lowest values of density and no statistic difference among means.

\subsection{Compressive Strength}

Figure 4 shows results of compressive strength for cement-wood composites, whose values are presented in Table 4 . Results agree with others reported by literature $[3,4$, $7,8]$.

Results showed that compressive strength was influenced by wood species. Cement-wood composites with $100 \%$ of Pinus elliottii sawdust showed better performance regarding compressive strength when sawdust particles were 
pre-treated by cement coating. Samples with blends of Pinus elliottii and Eucaliptus grandis follow the same behavior: higher percentages of Pinus elliottii and cement coating particle treatment tend to result higher values of compressive strength. Considering samples with $100 \%$ of Eucaliptus grandis, higher values of compressive strength were reached with in natura sawdust.

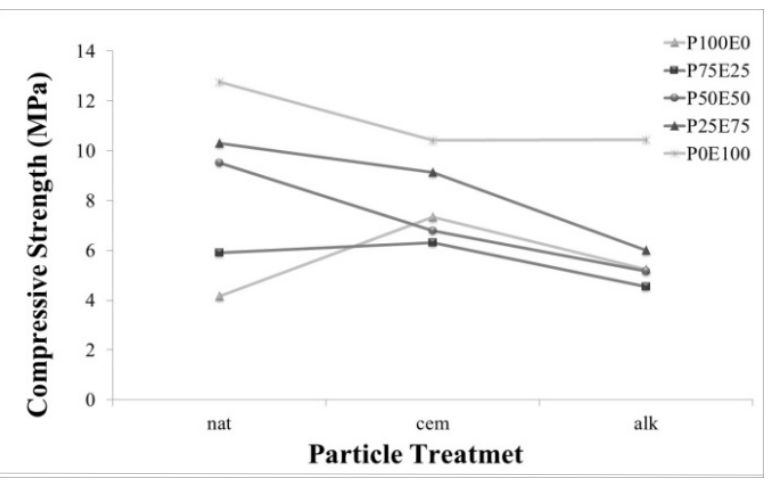

Figure 4. Compressive Strength of cement-wood composites

A previous study of cement-wood composites with in natura Pinnus $s p$. sawdust and cement: wood: water ratio of 1:0.21:0.6 resulted in a compressive strength mean of $5 \mathrm{MPa}$ [8], which is compatible to the mean value of $4.16 \mathrm{MPa}$ (Table 4), for $\mathrm{P} 100 \mathrm{E} 0_{\text {nat }}$ with cement: wood: water ratio of 1 : 00:48:0.60.

As a general trend, this research shows that the highest values of compressive strength are reached in composites with higher percentage of in natura Eucaliptus grandis sawdust. On the other hand, high percentages of in natura Pinus elliottii decreased the compressive strength.

Experimental results [20] of compressive strength tests

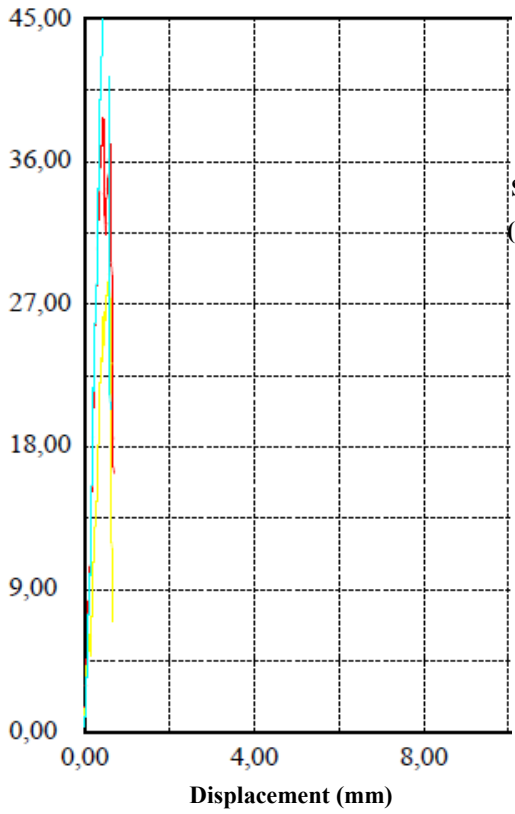

(a) performed in cement wood-composites show that Eucalyptus sawdust and cement are naturally compatible and do not require any previous particle treatment to avoid compatibility problems. Those results are aligned to the results found in the present study. These results, regarding composites with Eucaliptus sawdust are very important for industrial purposes, since the Eucaliptus wood is the most important raw material for cellulose and paper industry in Brazil [21] and the wood processing leads to a great amount of waste.

Table 4. Compressive strength of cement-wood composites

\begin{tabular}{|c|c|c|c|}
\hline Composite & $\begin{array}{r}\text { Compressi } \\
\text { (M }\end{array}$ & $\begin{array}{l}\text { Strength } \\
\text { a) }\end{array}$ & CV (\%) \\
\hline $\mathrm{P} 100 \mathrm{E} 0_{\text {nat }}$ & 4.16 & a & 3.53 \\
\hline $\mathrm{P} 100 \mathrm{E} 0_{\text {cem }}$ & 7.35 & e & 3.88 \\
\hline $\mathrm{P} 100 \mathrm{E} 0_{\mathrm{alk}}$ & 5.23 & abcd & 0.97 \\
\hline $\mathrm{P} 75 \mathrm{E} 25_{\text {nat }}$ & 5.90 & bcde & 2.06 \\
\hline $\mathrm{P} 75 \mathrm{E} 25_{\mathrm{cem}}$ & 6.30 & cde & 2.36 \\
\hline P75E25 $5_{\text {alk }}$ & 4.55 & $\mathrm{ab}$ & 0.83 \\
\hline P50E50 $0_{\text {nat }}$ & 9.52 & $\mathrm{f}$ & 3.38 \\
\hline $\mathrm{P} 50 \mathrm{E} 50_{\mathrm{cem}}$ & 6.78 & de & 1.83 \\
\hline $\mathrm{P} 50 \mathrm{E} 50_{\mathrm{akl}}$ & 5.17 & abc & 2.54 \\
\hline $\mathrm{P} 25 \mathrm{E} 75_{\text {nat }}$ & 10.30 & $\mathrm{f}$ & 0.72 \\
\hline $\mathrm{P} 25 \mathrm{E} 75_{\mathrm{cem}}$ & 9.12 & $\mathrm{f}$ & 1.49 \\
\hline $\mathrm{P} 25 \mathrm{E} 75_{\mathrm{alk}}$ & 6.00 & bcde & 4.09 \\
\hline P0E $100_{\text {nat }}$ & 12.77 & $\mathrm{~g}$ & 1.10 \\
\hline $\mathrm{P} 0 \mathrm{E} 100_{\text {cem }}$ & 10.42 & f & 1.59 \\
\hline P0E100 alk & 10.45 & f & 1.41 \\
\hline
\end{tabular}

$\mathrm{CV}=$ Coefficient of variation. Same letters imply treatments with equivalent means.

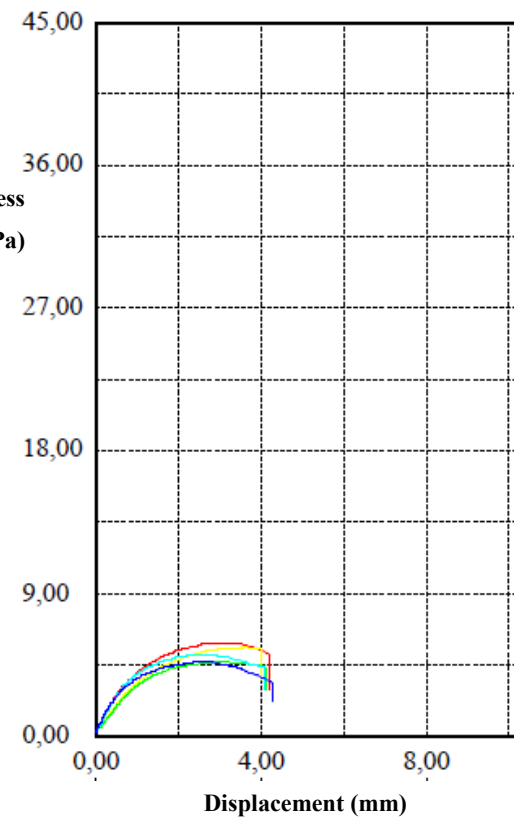

(b)

Figure 5. (a) Brittlebehavior of a cement paste; (b) Tough behavior of the $\mathrm{P} 100 \mathrm{E} 0_{\text {cim }}$ cement-wood composite 
Eucaliptus grandis sawdust pre-treated by immersion in alkaline solution resulted lower compressive strength values compared to in natura sawdust. Mix proportions in which blends of both wood species were used (P25E75 P50E50 e P75E25) and sawdust particles were immersed in alkaline solution showed the lowest values of compressive strength and no statistic difference among means.

The bonding between the wood fiber and the cement may be chemical, physical, or a combination of both. At the interface between the wood fiber and the cement matrix, stress is transferred between the wood fiber and the cement
[7]. A strong or weak interfacial bonding influences the mechanical behavior of the composite. If a strong bonding exists, the result is a brittle material with high strength, as shown in Figure 5(a). On the other hand, a weak bonding results in a tougher material, lacking high strength (Figure $5(b))$.

Figure 6 shows Stress versus Displacement behaviour of cement-wood composites with in natura Eucaliptus grandis sawdust, during compressive strength tests, which results are presented in Table 4.

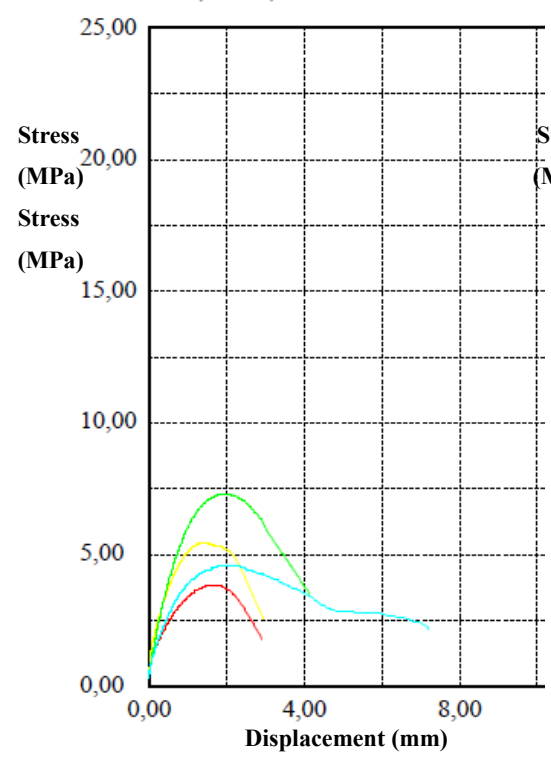

(a)

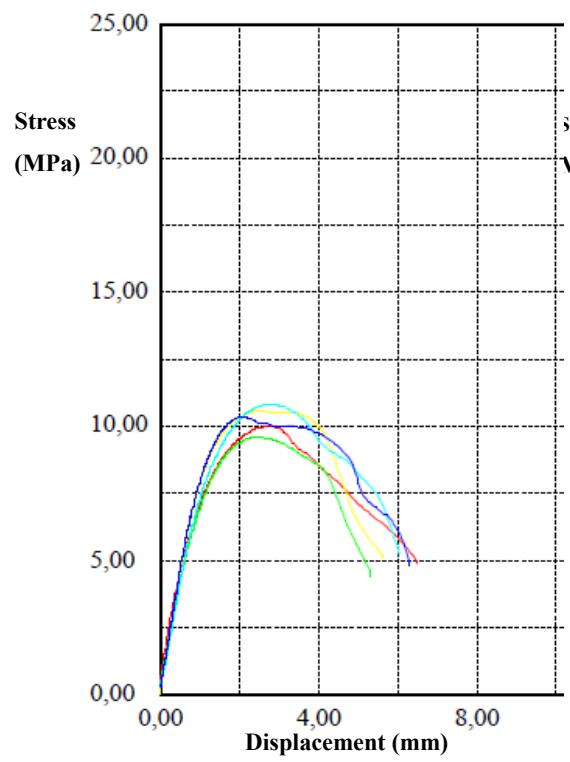

(c)

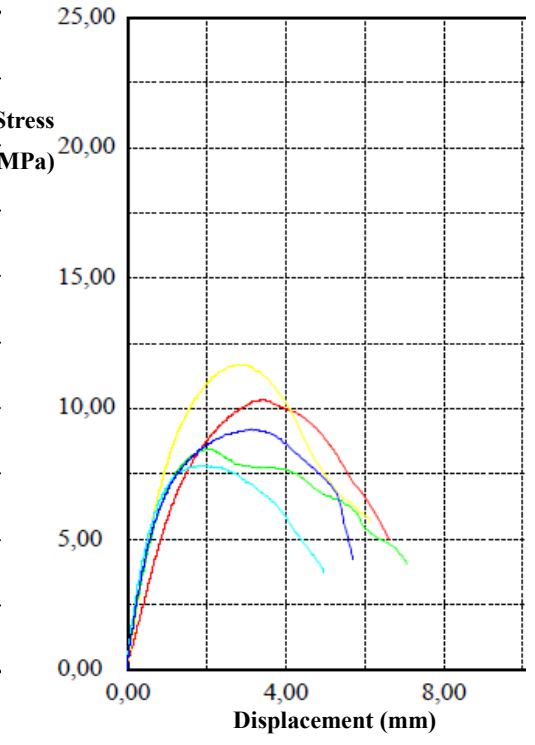

(b)

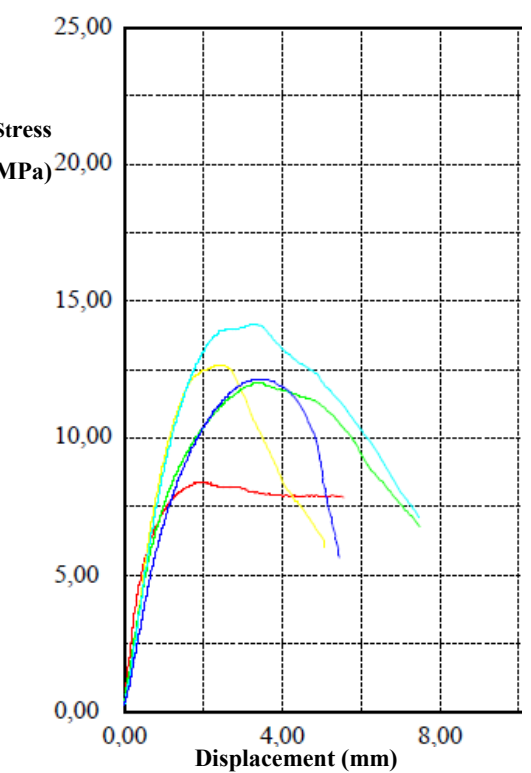

(d)

Figure 6. Stress $x$ Displacement behavior of cement-wood composites with different percentage of in natura Eucaliptus grandis sawdust: (a) P75E25; (a) P50E50; (a) P25E75; (a) P0E100 
The tough material behavior of the cement-wood composites that shows the efficiency of load transfer between matrix and wood fiber can be verified in Figure 6, as well as the increase in the compressive strength with the higher percentage of in natura Eucaliptus grandis sawdust.

\subsection{Dynamic Modulus of Elasticity}

The importance of determining the modulus of elasticity refers to the fact that this mechanical property is directly related to stiffness, deformability and cracking control of cement-wood composites [22]. The modulus of elasticity of a cement paste depends basically on its porosity and water: cement ratio. However, in a cement-wood composite, the proportion between paste and aggregate, the wood specie and wood particle treatments may also be relevant.

Figure 7 shows results of dynamic modulus of elasticity for cement-wood composites, whose values are presented in Table 5. Results agree with others reported by literature $[3,4$, $8,9]$

Table 5. Modulus of Elasticity of cement-wood composites

\begin{tabular}{|c|c|c|c|}
\hline \multicolumn{3}{|c|}{$\begin{array}{l}\text { Dynamic Modulus of } \\
\text { Elasticity }(\mathrm{MPa})\end{array}$} & \multirow{2}{*}{$\begin{array}{l}\text { CV }(\%) \\
9,21\end{array}$} \\
\hline $\mathrm{P} 100 \mathrm{E} 0_{\text {nat }}$ & 1356,61 & $\mathrm{a}, \mathrm{b}$ & \\
\hline $\mathrm{P} 100 \mathrm{E} 0_{\mathrm{cem}}$ & 2548,79 & $\mathrm{e}$ & 4,61 \\
\hline $\mathrm{P} 100 \mathrm{E} 0_{\text {alk }}$ & 1231,58 & a & 3,47 \\
\hline $\mathrm{P} 75 \mathrm{E} 25_{\text {nat }}$ & 2843,76 & $\mathrm{f}$ & 4,41 \\
\hline $\mathrm{P} 75 \mathrm{E} 25_{\mathrm{cem}}$ & 3324,74 & $\mathrm{~g}$ & 4,35 \\
\hline $\mathrm{P} 75 \mathrm{E} 25_{\mathrm{alk}}$ & 2188,59 & $\mathrm{c}, \mathrm{d}$ & 4,05 \\
\hline P50E50 nat & 2108,38 & $\mathrm{c}, \mathrm{d}$ & 8,07 \\
\hline $\mathrm{P} 50 \mathrm{E} 50_{\mathrm{cem}}$ & 2778,16 & $\mathrm{e}, \mathrm{f}$ & 4,36 \\
\hline $\mathrm{P} 50 \mathrm{E} 50_{\mathrm{akl}}$ & 1959,85 & $\mathrm{c}$ & 5,44 \\
\hline $\mathrm{P} 25 \mathrm{E} 75_{\text {nat }}$ & 3016,93 & $\mathrm{f}$ & 4,02 \\
\hline $\mathrm{P} 25 \mathrm{E} 75_{\mathrm{cem}}$ & 2947,05 & $\mathrm{f}$ & 10,53 \\
\hline $\mathrm{P} 25 \mathrm{E} 75_{\text {alk }}$ & 1492,32 & $\mathrm{~b}$ & 10,35 \\
\hline P0E100 nat & 2828,18 & $\mathrm{f}$ & 8,34 \\
\hline P0E $100_{\text {cem }}$ & 2063,79 & d & 8,01 \\
\hline $\mathrm{P} 0 \mathrm{E} 100_{\text {alk }}$ & 1554,89 & ${ }^{b}$ & 4,37 \\
\hline
\end{tabular}

$\mathrm{CV}=$ Coefficient of variation. Same letters imply treatments with equivalent means.

The modulus of elasticity of Pinus and Eucaliptus may range from $7 \mathrm{GPa}-13 \mathrm{GPa}$ and $12 \mathrm{GPa}-19 \mathrm{GPa}$, respectively. As a result of that, the mechanical behavior of cement-wood-composites, especially regarding stiffness and deformability, may vary considerably if blends of woods species are used.

Experimental results (Table 5) showed the influence of the wood species in the modulus of elasticity. Although composites with high amount of Eucaliptus grandis sawdust (P25E75 and P0E100) showed the highest values of compressive strength (Figure 4), such composites did not present the same behavior regarding modulus of elasticity.

The high coefficient of variation (Table 5) may result from the heterogeneity of the cement-wood samples but also may occur because several factors such as path length, moisture content, temperature, shape and size of specimen may affect ultrasonic measurements.

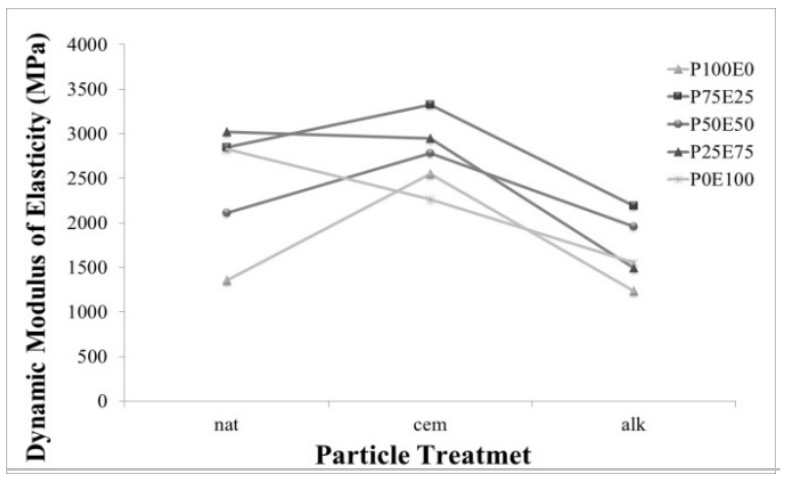

Figure 7. Dynamic modulus of elasticity of cement-wood composites

The influence of the aggregate in the modulus of elasticity sometimes may be more relevant than strength or age. For composites with different types of aggregate this influence may be even more complex [23]. In this research, it was found that different composites with same range of strength may present very different modulus of elasticity and it is assumed that these results come from aggregate influence.

Figure 8 shows dynamic modulus of elasticity of cement-wood composites with statistical data of comparison between means, where same letters imply treatments with equivalent means. Composite P75E25 with particles pre-treated by cement coating showed the highest value of modulus of elasticity.

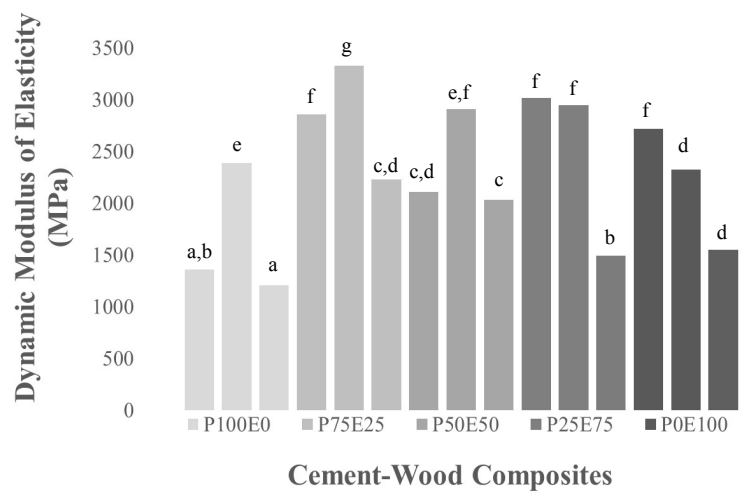

Figure 8. Dynamic modulus of elasticity of cement-wood composites with statistical data of comparison between means

Cement-wood composites with $100 \%, 75 \%$ and $50 \%$ of Pinus elliottii sawdust and particles pre-treated by cement coating showed better performance regarding modulus of elasticity. Composites P100E0 and P50E50 showed no statistic difference among means for particles pre-treated by immersion in alkaline solution.

Composites with $100 \%$ of Eucaliptus grandis sawdust showed best results regarding modulus of elasticity for in natura sawdust, followed by cement coating and immersion in alkaline solution treatments.

The interfacial bond strength between the fiber and the 
cement matrix is influenced by the moisture content due to the reduced bending strength of wet fiber, making it more flexible and less likely to inhibit cracking in the cement matrix [3]. Thus, considering the hygroscopic behavior of wood, the modulus of elasticity of a cement-wood composite is lower than the one of the cement paste itself, and tends to decrease the higher the percentage of wood.

\section{Conclusions}

Results showed that, wood species, particle treatments and mix proportions might influence the physical and mechanical properties of cement-wood composites.

Blends of Eucalyptus grandis and Pinus ellioti sawdust led to intermediate values of density, intermediate to lower values of compressive strength and intermediate to higher values of dynamic modulus of elasticity. Composites with $100 \%$ of Eucalyptus grandis showed higher values of compressive strength. Lighter composites were obtained with Pinus ellioti sawdust.

In general, results confirm that Eucalyptus sawdust and cement are naturally compatible and do not require any previous particle treatment to avoid compatibility problems.

\section{REFERENCES}

[1] C. Jürgensen, W. Kollert, A. Lebedys, 2014, Assessment of industrial roundwood production from planted forests, Planted Forests and Trees Working Paper Series, FAO $\mathrm{FP} / 48 / \mathrm{E}$

[2] N. Soltani, A. Bahrami, M.I. Pech-Canul, L.A. González, 2015 , Review on the physicochemical treatments of rice husk for production of advanced materials, Chemical Engineering Journal, 264, 899-935.

[3] S. Frybort, R. Mauritz, A. Teischinger, U. Muller, 2008, Cement bonded composites - A mechanical review, BioResourches, 3(2), 602-626.

[4] R. M. Ronquim, F. S. Ferro, F. H. Icimoto, C. I. Campos, M. s. Bertolini, A L. Christoforo, F. A. R. Lahr, 2014, Physical and Mechanical Properties of Wood-Cement Composite with Lignocellulosic Grading Waste Variation, International Journal of Composite Materials, 4(2), 69-72.

[5] M. Fan, M. K. Ndikontar, X. Zhou, J. H. Ngamveng, 2012, Cement-bonded composites made from tropical woods: Compatibility of Wood and cement, Construction and Building Materials, (36), 135-140.

[6] X. Lin, M. R. Silsbee, D. M. Roy, R. Kessler, P. R. Blankenhorn, 1994, Approaches to improve the properties of wood fiber reinforced cementitious composites, Cement and Concrete Research, 24(8), 1558-1566.

[7] J. L. Pehanicha, P. R. Blankenhorna, M. R. Silsbeeb, 2004, Wood fiber surface treatment level effects on selected mechanical properties of wood fiber-cement composites, Cement and Concrete Research, 34, 59-65.
[8] M. S. Bertolini, C. I. Campos, A. M. Souza, T. H. Panzera, A. L. Christoforo, F. A. R. Lahr, 2014, Wood-cement composites from wastes of Pinus sp. wood: Effect of particles treatment. International, Journal of Composite Materials, 4(2), 146-149.

[9] A. Ashori, T. Tabarsa, F. Amosi, 2012, Evaluation of using waste timber railway sleepers in wood-cement composite materials, Construction and Building Materials, 27, 126-129.

[10] A. Bahrami, N. Soltani, M.I. Pech-Canul, C.A. Gutiérrez, 2016, Development of metal-matrix composites from industrial/agricultural waste materials and their derivatives, Critical Reviews in Environmental Science and Technology, 46, 143-208.

[11] F C. Jorge, C. Pereira, J. M. F. Ferreira, 2004, Wood-cement composites: a review, Holz Roh Werkst, 62, 370-377.

[12] ABNT. Brazilian Technical Standards Association. NBR 5733: High Early Strength Portland Cement. Rio de Janeiro, 1991.

[13] S. A. Costa, "Incorporação de serrim em argamassas cimentícias", M. Eng. Thesis, Universidade do Minho, Guimarães, Portugal, 2012.

[14] ABNT. Brazilian Technical Standards Association. NBR 7115: Calcium Hydroxide for mortars - Requirements. Rio de Janeiro, 2003.

[15] ABNT. Brazilian Technical Standards Association. NM 248: Particle Size Distribution. Rio de Janeiro, 2003.

[16] ABNT. Brazilian Technical Standards Association. NBR 7215: Compressive Strength of Cement. Rio de Janeiro, 1996.

[17] ABNT. Brazilian Technical Standards Association. NBR 15630: Mortars - Determination of dynamic modulus of elasticity by ultrasonic wave propagation. Rio de Janeiro, 2008 .

[18] M. R Garcez, T. Santos, D. A. Gatto, 2013, Avaliação das propriedades físicas e mecânicas de concretos pré-moldados com adição de serragem em substituição ao agregado miúdo, Ciência \& Engenharia, 22, 95-104.

[19] S. Iwakiri, A. B. M. Stinghen, E. L. Silveira, E. H. C. Zamarian, J. G. Prata, M. Bronoski, 2008, Influência da massa específica sobre as propriedades mecânicas de painéis aglomerados, Floresta, 38(3) 487-493.

[20] V. Castro, R. D. Araújo, C. Parchen, S. Iwakiri, 2014, Avaliação dos efeitos de pré-tratamentos da madeira de Eucalyptus benthamii Maiden \& Cambage no grau de compatibilidade com cimento Portland, Árvore, 38(5), 935-942.

[21] A. L. Beraldo, J. V. Carvalho, 2004, Compósito de Eucalyptus Grandis - cimento Portland, Scientia Forestalis, $65,150-161$.

[22] A. L. Christoforo, S. L. M. Ribeiro Filho, T. H. Panzerai, F. A. R. Lahri, 2013, Metodologia para o cálculo dos módulos de elasticidade longitudinal e transversal em vigas de madeira de dimensões estruturais, Ciência Rural, 43(4), 610-615.

[23] A. L. Gutierrez, M F. Cánovaz, The modulus of elasticity of high performance concrete, 1995, Materials and Structures, $28,559-568$. 